\title{
Enteral nutrition in surgical patients
}

\author{
Vasyliy Syplyviy ${ }^{1, a^{*}}$, Sergiy Grinchenko ${ }^{2, b}$, Valentina Shadrina ${ }^{3, \mathrm{c}}$ \\ 1, 2, 3Ukraine, Kharkiv National Medical University, Department of General Surgery № 2 \\ asyplyviy@ukr.net, brinchenko_sergey@ukr.net, cms.tinawolf@mail.ru
}

Keywords: enteral insufficiency syndrome, enteral nutrition, form of enteral insufficiency.

\begin{abstract}
In this research work there was studied the problem of syndrome of enteral insufficiency in surgical patients, to determine the degree of enteral insufficiency it was made by assessing the main clinical, laboratory and instrumental methods of examination of patients with the amount of points for each of the criteria. It suggested early enteral nutrition including postoperative differentially, depending on the form of enteric disease. We observed 40 patients who were divided into two groups. In the first group, 21 (52.5\%), early enteral nutrition was conducted. The second group - 19 (47.5\%), parenteral nutrition was conducted in the postoperative period. As a result of observations in patients who received early enteral nutrition, there was normalization of the gastrointestinal tract for 2-3 hours. In connection with this technique of enteral nutrition designed depending on the form of enteric disease, which promotes more rapid restoration of vital organs and systems.
\end{abstract}

\section{Introduction.}

In surgical practice management of patients in the postoperative period has played a leading role in the treatment and outcome of the underlying disease. Any surgery on the abdominal organs, even in the absence of marked postoperative complications is a stress factor for the gastrointestinal tract and the whole body $[1,3,4,12]$. If to this unfavorable background join postoperative complications, as well as in cases where surgery is caused such severe pathology like peritonitis or acute intestinal obstruction, the patient's condition in the postoperative period is extremely difficult. During this stressful period included compensatory- adaptive reactions of the body, including the central place given to enteric disease $[1,2,5,12]$.

Enteral insufficiency - a clinical syndrome caused by the digestive absorption of the small intestine dysfunction, characterized by intestinal and extraintestinal manifestations, which are based on the acquired or hereditary defects deterministic enzyme systems leading to metabolic disorders. Development of enteric disease, and there is a compensatory mechanism, which consists in inhibition of motor-evacuation activity of the gastrointestinal tract, increase the secretory activity of the stomach, small intestine and colon, reabsorbtion increase the ability of the kidneys, slowing excretion of salts and water, which, in turn, leads to serious violations of the acid ground state and metabolism in general, reducing the efforts of the surgeon. Thus, the solution to the problem of enteric disease as one of the terrible post-operative complications, remains extremely relevant.

In the course of many years of work on the problems of enteral insufficiency we have seen that an essential component of intensive care enteral insufficiency syndrome in postoperative patients is an adequate balanced diet, which, depending on the patient's condition can be parenteral and enteral (probe) using a customized nutrient mixtures. The latter is the most effective, so go to it immediately with minimal adjustment of gastrointestinal function [ $8,9,10,13]$.

Enteral nutrition nutritious blends - a kind of nutritional support, in which the nutrients come through the probe as part of a balanced nutritional formulas if you can not adequately oral nutrition. Enteral nutrition nutritious blends shown to all patients with advanced enteric failure who maintained or minimally restored gastrointestinal function. The appointment of enteral feeding 
short-course (less than 2 weeks) suitable villa mixture through nasogastric tubes of different modifications $[6,7,11,13]$.

Nutritious blends of these factors need to be considered when appointing enteral nutrition:

- Severity of enteric disease and the degree of severity of the patient

- The degree of energy needs

- Degree in protein needs

- The degree of fluid needs

To assess the severity of enteric disease caused by peritonitis we recommend using our specially developed scale. This rating scale enteric disease has been developed by us in the course of many years of experience treating enteral insufficiency in patients with peritonitis of different etiology.

Scale refers to the separation of enteric disease assessment parameters when peritonitis 4 groups. The first group included the most important for assessing clinical symptoms, detectable by physical inspection of the patient: the nature of abdominal pain, the presence of symptoms of irritation of the peritoneum, the volume of the stomach contents on probing, systolic blood pressure and heart rate (as the main indicators of hemodynamics), respiratory rate ,temperature of body.

Interpretation of the data derived from clinical evaluation of enteral insufficiency on the proposed scale is as follows: when the amount of up to 20 points enteral insufficiency is considered compensated at the amount of 21 to 40 points - subcompensated, with an increase in the number of 41 or more - decompensated (table 1, the patent No 28863).

The purpose of this study was to optimize the administration of adequate enteral nutrition in one form or another enteric disease in surgical patients.

\section{Materials and methods.}

We observed 40 patients aged 19-64 years, are treated at the surgical department of the Kharkiv Regional Clinical Hospital №18 and Multidisciplinary Clinical Hospital in Kharkiv. These patients had a clinical picture of enteric disease and, depending on the severity of the latter, according to a scale of scores for enteral failure in 20 patients $(50 \%)$ diagnosed compensated form of enteral insufficiency, 9 patients $(22.5 \%)$ - subcompensated form, 11 patients had a hospital enteral insufficiency in decompensated form $(27.5 \%)$. $[7,8,12]$.

Patients depending on getting treatment, were divided into two groups. The first group consisted of 21 patients $(52.5 \%)$ who received early enteral nutrition nutritious blends. Today the pharmaceutical market offers sufficient assortment of mixtures for enteral feeding probe with high efficiency and excellent tolerability of patients with different easy digestibility, sound absorption, balanced protein profile, isocaloric with an adequate distribution of energy between proteins, fats and carbohydrates. Introduction enteral mixtures patients of the first group, depending observed in these forms had its characteristics shown in Table 2.

The second group consisted of 19 patients $(47.5 \%)$ who received parenteral nutrition: 10 diagnosed with compensated (52.6\%), and 5 - subcompensated (26.3\%), from 4 - decompensated a $(21.1 \%)$ form of enteric disease. Conducted parenteral administration of amino acids, salt solutions ,enzyme preparations, massive vitamino- and immunomodulating therapy, the introduction of the mixtures for enteral feeding was carried out. 
Table 1. Scale diagnosis and clinical assessment of enteral insufficiency, caused by peritonitis

\begin{tabular}{|c|c|c|c|}
\hline \multicolumn{2}{|c|}{ Points } & $\mathbf{2}$ & \multicolumn{2}{|c|}{} \\
Indicators & \multicolumn{2}{|c|}{ cramping } & spills, persistent \\
\hline \multicolumn{2}{|c|}{ Indicators of physical examination } \\
\hline $\begin{array}{c}\text { Character of abdominal } \\
\text { pain }\end{array}$ & aching & blow (soft) & swelling (tense) \\
\hline Abdominal distention & absent & dubious & positive \\
\hline $\begin{array}{c}\text { Peritoneal symptoms } \\
\text { stomach contents by the } \\
\text { probe }\end{array}$ & negative & $800-1200 \mathrm{ml}$ & more than 1200 \\
upl to $800 \mathrm{ml}$
\end{tabular}

Radiographic indicators

\begin{tabular}{|c|c|c|c|}
\hline \multicolumn{1}{|c|}{ Pneumatosis } & Colon & The small intestine & $\begin{array}{c}\text { The small intestine } \\
\text { and colon }\end{array}$ \\
\hline \multicolumn{1}{|c|}{ Kloyber's bowls } & The small intestine & $\begin{array}{c}\text { The small intestine } \\
\text { (a lot) }\end{array}$ & $\begin{array}{c}\text { The small intestine } \\
\text { and colon }\end{array}$ \\
\hline $\begin{array}{l}\text { The high standing of the } \\
\text { diaphragm domes }\end{array}$ & absent & doubtfully & positively \\
\hline $\begin{array}{l}\text { Symptom Casey (edema } \\
\text { Kerckring folds ) }\end{array}$ & absent & doubtfully & expressed \\
\hline
\end{tabular}

Indicators identified intraoperatively

\begin{tabular}{|c|c|c|c|}
\hline Peritonitis & absent & local, diffuse & spilled \\
\hline $\begin{array}{c}\text { The nature of fluid in the } \\
\text { abdominal cavity }\end{array}$ & serous & $\begin{array}{c}\text { serous, } \\
\text { fibrinous }\end{array}$ & $\begin{array}{c}\text { purulent, } \\
\text { stercorous, } \\
\text { putrefactive }\end{array}$ \\
\hline $\begin{array}{c}\text { Bowel wall infiltration } \\
\text { there are areas of } \\
\text { necrosis and } \\
\text { thinning }\end{array}$ \\
\hline $\begin{array}{c}\text { Diameter of the small } \\
\text { intestine }\end{array}$ & up to $3 \mathrm{sm}$ & $3-5 \mathrm{sm}$ & $\begin{array}{c}\text { higher 5 sm, } \\
\text { gas + liquid }\end{array}$ \\
\hline Peristalsis of intestine & saved & sluggish & absent \\
\hline
\end{tabular}


Table 2. Enteral nutrition in patients of the first group ( 21 pers.)

\begin{tabular}{|l|l|}
\hline \multicolumn{1}{|c|}{$\begin{array}{c}\text { The form of enteral } \\
\text { insufficiency }\end{array}$} & \multicolumn{1}{c|}{ Treatment and enteral nutrition } \\
\hline $\begin{array}{l}\text { compensated } \\
(10 \text { patients }-47.6 \%)\end{array}$ & $\begin{array}{l}\text { oral fluid is 2-4 hours with the additional appointment of one of the } \\
\text { nutrient mixtures for enteral nutrition }\end{array}$ \\
\hline $\begin{array}{l}\text { subcompensated } \\
(5 \text { patients }-23.8 \%)\end{array}$ & $\begin{array}{l}\text { 1) entering the intestinal sensing of Treitz ligament, followed by } \\
\text { active aspiration of intestinal contents } \\
\text { 2) after 24 hours - enteral administration of saline solutions, glucose, } \\
\text { electrolytes. } \\
\text { 3) after 48 hours - the appointment of a nutrient mixtures for enteral } \\
\text { nutrition through a tube. }\end{array}$ \\
\hline $\begin{array}{l}\text { decompensated } \\
(6 \text { patients }-28.6 \%) \\
\text { of to the intestinal sensing Bauginievaya flaps followed by aspiration } \\
\text { 2)after 24 hours, depending on the degree of impairment of } \\
\text { consciousness, enteral administration of saline solution, followed by } \\
\text { the introduction of oxygen active aspiration. } \\
\text { 3)after 48 hours of assigned drug stimulation of peristalsis by } \\
\text { assigning Cerucalum, neostigmine or other means + oral liquids } \\
\text { 4) after 72 hours - the appointment of a nutrient mixtures for enteral } \\
\text { nutrition }\end{array}$ \\
\hline
\end{tabular}

\section{Results and discussion.}

The first group of patients with compensated enteral insufficiency in 10 patients $(47.6 \%)$ treated with a mixture including other preparations for enteral nutrition, there was a complete recovery of gastrointestinal function and 2-3-day. Normalization gastrointestinal function in 10 patients with compensated enteral insufficiency of the second group $(52.6 \%)$ treated with parenteral nutrients, was more delayed - for 4-5 hours. Similar results were obtained by analyzing the results of treatment of patients with subcompensated form of enteric disease: 5 patients of the first group (23.8\%) who received enteral enteral nutrition, on the 3rd day marked the normalization of gastrointestinal function; in 5 patients $(26.3 \%)$ treated with parenteral nutrients, similar results were achieved after 5 days.

In the first group of patients with decompensated enteral insufficiency $(6,28.6 \%$, patients) in 5 (23.8\%) patients was marked clinical improvement in gastrointestinal functions and normalization on the third day, 1 patient ( $4.8 \%$ ) failed to prevent the development of multiorgan failure, resulting in death occurred. Among 4 patients $(21.1 \%)$ of the second group with decompensated insufficiency stabilization occurred in 2 patients $(10.5 \%)$ for 6 hours, 2 people $(10.5 \%)$ died as a result of which developed multiple organ failure.

\section{Conclusions.}

As a result, the clinical observation of the above-mentioned groups of patients we noted that the use shown in Table 2 of tactics, coupled with the most early appointment of enteral nutrition contributes to more rapid recovery of the functions of vital organs and systems, which is one of the key factors for a speedy recovery of the patient and the prevention of multiple organ failure. 


\section{References}

[1] A.A.Uzankichian, A.R. Asatrian, A.E. Zakarian [et al.], Pathogenesis of enteral insufficiency in patients with postoperative peritonitis, Khirurgiia (Mosk). (11)42 (2010) 22-26.

[2] Ed. L. Sobotka, Fundamentals of Clinical Nutrition, Proceedings of lectures for courses of the European Association of parenteral and enteral nutrition, 2nd ed, Petrozavodsk, 2003.

[3] I.N. Leiderman, A.V. Nikolaenko, O.G. Sivkov, Nutritional support in intensive care unit. Algorithms and protocols Standards, A Guide for Physicians, 2006.

[4] L.A. Maltseva, L.V. Usenko, N.F. Mosentsev, S.O. Kosulnikov, S.A. Volkov, and others Gastrointestinal failure, ways of diagnosis and correction, Dnepropetrovsk, Nova Ideologiya, 2006.

[5] L.V. Usenko, L.A. Maltseva, The theoretical background and practical bases of nutritional support in the hospital critical states, Monograph, Dnepropetrovsk, ART Press, 2008.

[6] N.V. Kharchenko, V.V. Chernenko, Modern approaches to the correction of intestinal dysbiosis, Method. Recommended, Kyiv, 2000.

[7] S.V. Grinchenko, V.O. Siplivyi, E.A. Shapovalov [et al.], Sposib otsinki tyazhkosti gostroï enteralnoï nedostatnosti, Patent No. 28863, Ukraine, 2007.

[8] S.V. Grinchenko, V.O. Siplivyi, E.A. Shapovalov [et al.], Sposib hirurgichnoï korektsiyi gostroyi enteralnoyi nedostatnosti, Patent No 28861, Ukraine, 2007.

[9] S. Wang, L. Ma, Y. Zhuang et al., Screening and risk factors of enteral insufficiency in critically ill adult patients receiving enteral nutrition, Crit Care. 17(4). (2013) 163-167.

[10] V.A. Michelson, Specialised clinical nutrition - additional possibilities of normalization of carbohydrate metabolism in surgery and intensive care, Journal of Intensive Care. 3 (2005) 68-73.

[11] V.A. Rudnov, Nitritiv support in sepsis: if there are arguments in favor of a specific protocol?, Anestez.-Rean. 6 (2006) 9-12.

[12] V.A. Siplivyi, S.V. Grinchenko, A.V. Beresnev, The scale of the risk stratification of patients with acute sepsis, Klinichna hirurgiya. 3 (2005) 46-49.

[13] V.I. Hrupkin, M.D. Hanevich, A.E. Shestopalov [et al.], Enteric intestinal insufficiency syndrome therapy in patients with peritonitis, Bulletin of surgery. 6 (2003) 16-19. 